Бондарчук С. В.

(0000-0003-0624-9782);

Галаган В. І., канд. військ. наук, доцент

(0000-0001-9578-0895);

Беляченко В. В.

(0000-0003-3938-5158);

Мулявка А. С.

(0000-0002-3113-0719)

Центр воєнно-стратегічних досліджень Національного університету оборони України імені Івана Черняховського, Київ

\title{
Обгрунтування фахової компетенції учасників робочої групи щодо розроблення, впровадження та супроводження інформаційних систем військового призначення
}

Резюме. У статті розглянуто проблему єдиного розуміння компетенцій фахівців-аналітиків, яких залучають під час розроблення, впровадження та супроводження інформаційних систем. Запропоновано їх можливу класифікацію для IT-сфери Збройних Сил України.

Ключові слова: аналітики в IT-сфері, класифікації IT-аналітиків, вимоги та навички IT-аналітиків.

Постановка проблеми. Міністерство оборони України (далі - Міноборони) знаходиться на етапі опрацювання концептуальної моделі оборонного менеджменту. Зазначена модель має поєднати у єдиному безперервному процесі оборонне планування на основі спроможностей із плануванням та управлінням оборонними ресурсами, а також формуванням i виконанням державного бюджету в частині, що стосується Міноборони. До того ж, в основу майбутнього оборонного менеджменту закладаються принципи i підходи, прийняті в державах-членах НАТО, а також сучасні бізнес-практики, адаптовані для програмно-проєктного управління розвитком Збройних Сил України [1].

У більшості фахових публікацій [2-4] 3 розроблення та впровадження інформаційних систем (далі - IC) не має чіткого поняття щодо складу робочої групи та порядку розв'язання проблемних питань, які виникають під час цього процесу. Водночас у наукових роботах, які виконуються в науково-дослідних установах ЗС України неодноразово проводився детальний аналіз цього питання.

На сьогодні змінився підхід до вдосконалення та впровадження подібних систем, який більше спирається на управління спроможностями, що відповідає сучасним тенденціям в IT-сфері та дає змогу перейти на новий рівень без проміжних етапів i впроваджувати нові підходи до створення та вдосконалення наявних IC [5].

Проблема залучення фахівців 3 необхідними компетенціями [6] під час розроблення, впровадження та супроводження IC, окрім фінансових, полягає ще й у відсутності єдиного розуміння щодо їх компетенції.

Аналіз останніх досліджень та публікацій. Проведений аналіз показав, що нині на професію "системний аналітик" чи "бізнес-аналітик" Міністерством соціальної політики України навіть не визначено стандарту [7]. Найбільш близькими за функціями до аналітика в професійному стандарті $є$ “фахівець 3 інформаційних систем”. Питанням компетенції фахівціваналітиків, які залучаються під час розроблення, впровадження та супроводження інформаційних систем, приділяється недостатня увага.

Водночас світові провідні установи (Міжнародний інститут бізнес-аналізу International Institute of Business Analysis, IIBA) мають власну систему кваліфікації та сертифікації таких фахівців [8].

На жаль, передовий досвід щодо кваліфікації та сертифікації фахівціваналітиків в управлінні проєктами в державних установах, зокрема і ЗС України майже не використовується.

Зважаючи на викладене, метою статті $\epsilon$ вироблення єдиного розуміння щодо компетенції фахівців-аналітиків, які залучаються під час розроблення, впровадження та супроводження інформаційних систем та їх класифікації для IT-сфери Збройних Сил України.

Виклад основного матеріалу. Сьогодення потребує, щоб структури (організації) державного (зокрема i Збройні Сили України) та недержавного сектору враховували тенденції розвитку та методики 
впровадження i супроводження сучасних інформаційних систем.

Останні погляди експертів зводяться до того, що аналітичні фахівці інформаційної сфери $є$ однією із сучасних i необхідних професій. Вони потрібні в штаті будь-якої організації для виконання певних завдань на всіх етапах життєвого циклу IC. До того ж, чітко визначених вимог до вказаної спеціальності не існує.

Найбільш спорідненим до аналітичного фахівця є професійний стандарт “фахівець 3 інформаційних систем”, де визначена основна мета діяльності фахівців 3 інформаційних систем: “створення (модифікація) і супроводження IC, що автоматизують завдання організаційного управління та бізнес-процеси в організаціях різних форм власності". На нього покладається:

аналіз вимог до системи і процесів;

створення і введення в експлуатацію;

регламенти модифікації, оптимізації і розвитку;

здійснення планування, керівництва i координації різних видів діяльності у сфері створення і експлуатації бізнес-застосунків та додатків.

До того ж об'єктами і засобами його професійної діяльності є:

програми і програмні компоненти;

мови і системи програмування;

завдання на модифікацію, оптимізацію розвиток;

інструментальні засоби для

документування;

описи, аналіз і моделювання інформаційних і комунікаційних процесів в інформаційних системах;

інструментальні засоби управління проєктами;

стандарти i методи організації управління, обліку i звітності на підприємствах;

стандарти і методи інформаційної взаємодії систем.

Також цим документом визначені "Професійні назви робіт за кодами професій за Національним класифікатором України ДК 003:2010 “Класифікатор професій”:

2131.2 аналітик комп'ютерних систем;

2131.2 аналітик комп'ютерного банку даних;

2131.2 аналітик операційного та прикладного програмного забезпечення;

2131.2 аналітик програмного забезпечення та мультимедіа обчислень;
2149.2 аналітик

систем

(крім

комп'ютерів)

Проте в класифікаторі не зазначено професії "бізнес-аналітика" ("аналітика бізнес-додатків") та “системного аналітика", хоча в меті стандарту на професію такі завдання визначено [7].

Будь-яка структура (організація) може використовувати різноманітні програмні продукти. Наглядним прикладом $\epsilon$ ЗС України, які можна уявити великою розподіленою структурою (організацією), кожен програмний продукт якої, в ідеалі, має бути інтегрований 3 іншим. Така інтероперабельність дає змогу отримати будьяку інформацію, яка потрібна начальнику (командиру) цієї миті з найменшою кількістю маніпуляцій в одному програмному середовищі.

На жаль, під час ведення проєкту не кожен керівник повною мірою розуміє, що насправді робить аналітик і чим він корисний конкретному проєкту та вкладає в його діяльність щось своє, зрозуміле йому як фахівцю свого напряму.

Проведений раніше аналіз методик впровадження та супроводження IC, до яких можна віднести ГОСТ (ДСТУ) і RUP (ASAP, SCRUM) $[9,10]$ показує, що вони потребують формування певного переліку документів відповідними спеціалістами. До того ж склад і зміст документів до вимог може істотно різнитися. Набір атрибутів вимог у кожному документі наводиться свій, часто зовсім неоднозначний. Крім того, замовники IC часто плутають результати етапів аналізу i проєктування, змушуючи виконавців включати до аналітичних документів остаточний вигляд діаграми класів даних i повну схему баз даних. Вирішення цих завдань потребує залучення певних фахівців, що вимагає класифікувати IT-спеціалістів (аналітиків).

Фактично у сфері IT можна виділити два види спеціалізації ІТ-аналітиків:

системні аналітики;

бізнес-аналітики (ця роль належить не тільки до IT).

Незважаючи на завдання, які можуть бути ними вирішені, необхідні навички у них істотно різняться. На IT-проєктах здебільшого обидві спеціалізації об'єднує в собі один співробітник (або група співробітників). Іноді зустрічається i ïx поділ, наприклад, на проєктах для великих структур (організацій), але таких випадків незначна кількість. 
Загалом, можна визначити основні завдання IT-аналітиків.

Системний аналітик: збір; аналіз; формалізація і погодження розбіжностей між вимогами до системи, тобто управління вимогами до IC протягом усього їх життєвого циклу. Основний документ за розроблення і якість якого повинен відповідати системний аналітик - технічне завдання на створення IC або його аналог. Системний аналітик в обов'язковому порядку повинен мати хороший ІТ-досвід i бути здатним спілкуватися із замовниками, розробниками та користувачами продукції, а бізнес-аналітик тільки з користувачами.

Бізнес-аналітик: вивчення; опис; аналіз і (за необхідністю) реінжиніринг бізнеспроцесів. Основний документ за розроблення і якість якого повинен відповідати бізнесаналітик - опис бізнес-процесів "як $\epsilon$ " (As Is) i “як буде" (То Ве).

Словарний аналіз понять “системний аналіз" і “бізнес-аналіз” показує, що термін "система" трактується як "ціле, складене 3 частин; з'єднання". А слово "бізнес" перекладається 3 англійської “справа", "підприємство". Тобто аналітики виконують дії, що розвивають і змінюють предмет, який складається з частин (у разі системи) та дії, від яких залежить життедіяльність i працездатність структури (організації) - у разі бізнесу.

Детальніше класифікувати аналітиків залежно від завдань, які на них покладаються, можна так:

Бізнес-аналітик. Завдання, що покладаються на бізнес-аналітика найбільш деталізовано сформульовані у фундаментальних працях 3 описом професійного стандарту/зводу правил з бізнесаналізу, який розроблений міжнародним інститутом бізнес-аналізу (International Institute of Business Analysis, IIBA) під назвою BABOK (Business Analysis Body of Knowledge) [8], де визначено: “бізнес-аналітик - це співробітник компанії або учасник проєкту, який виявляє потреби для змін організації (організаційного розвитку), узагальнює їx, фіксує, класифікує і рекомендує рішення про зміну устрою діяльності компанії (процесів), обгрунтовує ці зміни для керівництва і бере участь у детальному їх розробленні та впровадженні”. Інше визначення надане Карлом Вігерсом і Джоєм Бітті [11], визначає завдання бізнес-аналітика як, “з'ясувати, для чого потрібна користувачам нова інформаційна система".
Зміни потрібні будь-якій організації (зокрема i для структур 3С України) для досягнення стратегічних цілей. До того ж стратегічні цілі можуть народжуватися як у середині організації, так і під впливом зовнішнього середовища. Наприклад, для ЗС України такими стратегічними цілями $\epsilon$ забезпечення оборони держави, створення збройних сил за принципами та стандартами, прийнятими в державах-членах НАТО, забезпечення відсічі агресору тощо. Отже, стратегічна ціль - це вигода для організації, яку вона отримає після впровадження нового рішення, яке забезпечує розгорнута інформаційна система. Тобто, бізнес-аналітик здійснює постійний контроль внутрішнього розвитку організації і реагує на будь-які його зміни. На цім зовнішні фактори, які впливають на організацію, також фіксуються та вивчаються. Так, бізнес-аналітик виявляє потреби діяльності організації і завжди може пояснити причину будь-яких змін. Значне територіальне та організаційне розгалуження організації значно збільшуе кількість різноманітних процесів та IT-систем, що викликає потребу в таких фахівцях.

Окрім бізнес-аналітика в структурі (організаціï), як правило присутній i системний аналітик. До того ж, якщо бізнеспроцеси не особливо складні, то такі завдання за обох фахівців може виконувати одна людина.

Системний аналітик. Системного аналітика часто характеризують як "постановника задач" - це досить чітке визначення, хоча повною мірою не відображає його сутність. Спеціальність "системний аналітик" також не має еталонного визначення, i межі його повноважень від проєкту до проєкту, від організації до організації, від середовища до середовища, можуть дуже різнитися. Буває так, що бізнесаналітик виступає як замовник для системного аналітика, який зі свого боку намагається зрозуміти бажання замовника, оцінюе адекватність вимог і можливість їх реалізації (як правило, оцінювання можливостей відбувається спільно з командою розробника i архітектором програмного продукту). Надалі системний аналітик переводить вимоги замовника на мову розробника i ставить завдання на розроблення. У такий спосіб системний аналітик $є$ умовним фільтром i перетворювачем між замовником i розробником.

Результатом роботи системного аналітика $є$ постановка завдання на створення 
системи чи іiі складової, програмного забезпечення, додатків. Оформлення напрацьованих результатів буде залежати від методології розроблення програмного продукту або ведення проєкту, та закінчується документом "Технічне завдання", у якому збираються всі вимоги, об'єднуються, систематизуються i описується системна постановка завдання.

Отже, системний аналітик стає з'єднуючою ланкою між впровадженням нового програмного продукту i вже впровадженим. Проте його робота на цьому не закінчується, він супроводжує етап розроблення, тестування, впровадження в середовище замовника, налаштування i супроводження, $\mathrm{i}$, якщо необхідно, подальший розвиток продукту. Тобто, системний аналітик здійснюе постійний контроль життевого ииклу програмного продукту і $\epsilon$ посередником між замовником $i$ командою розробника.

Залежно від методології розроблення процес може змінюватися, але функції, які виконує аналітик залишаються такими ж. На невеликих проєктах або на проєктах з досить простою бізнес-логікою, але складним розробленням, в обов'язки системного аналітика можуть бути включені обов'язки бізнес-аналітика, менеджера (координація виконання завдання, моніторинг строків виконання, виявлення проблем тощо), тестувальника, і навіть служби підтримки.

Проведений аналіз показав, що межа між функціоналом "бізнес-аналітика" i "системного аналітика" часто настільки незначна, що функції системного аналітика приписують бізнес-аналітику і навпаки.

Для виконання завдань, бізнес-аналітик спирається на свої знання, досвід і вимоги середовища роботи, вибирає спосіб фіксації результатів своєї діяльності, а саме фіксації вимог і їх рішень 3 реалізації у вигляді бізнеспроцесів. Відповідно і проміжним результатом роботи бізнес-аналітика $\epsilon$ набір документації $з$ описом нової будови організації в зміненій іiі частині.

Якщо, невеликі структури (організації) можуть поєднувати функціонали різноманітних аналітиків, то для такої великої та специфічної організації як ЗС України, одна посадова особа не може впоратися 3 усіма завданнями і мати настільки глибокі знання та володіти інструментами у всіх напрямах відразу, адже кожен 3 них потребує дедалі більш якісний результат від фахівця. Під впливом вимог сьогодення та розвитку інформаційного середовища 3 безліччю процесів, отримують подальший розвиток i інші напрями, які також мають “закриватися” певними спеціалістами аналітичної складової:

Аналітик-проєктувальник

(User

experience). Основна його функція проєктування інтерфейсів, яка грунтується на розробленні інтуїтивно-зрозумілого і зручного інтерфейсу призначеного для кінцевого користувача i спрощення вирішення поставлених завдань перед користувачем.

Проєктувальник інтерфейсу аналізує інформацію, яку збирає і фіксує системний аналітик і бізнес-аналітик. Найбільшу частину робочого часу, проєктувальник відводить під процес декомпозиції $\mathrm{i}$ розуміння вимог призначеного для користувача інтерфейсу, який відображає функціонал інформаційної системи. Аналітик мусить поставити себе на місце користувача і з'ясувати, як саме має працювати інтерфейс. До того ж він також аналізує поведінку людини і виконувані ним дії (бізнес-процеси). На основі цього аналітик проєктує призначений для користувача інтерфейс таким чином, щоб в ньому було зручно працювати і він задовольняв вимогам роботи 3 ним.

Отже, основне завдання аналітикапроєктувальника - підвищити користувацьку направленість інтерфейсу (usability), тобто зробити його зручним i зрозумілим, грунтуючись на поведінці цільової аудиторії користувачів продукту. Особливо важлива роль таких фахівців у проєктах багатокористувацьких систем, порталів.

На жаль, про цей клас аналітика часто забувають, i він може бути відсутній на проєктах. Його обов'язки покладають, як правило, на системного аналітика, який частіше дивиться на інтерфейс 3 погляду системи, а не користувача $\mathrm{i}$, проєктуючи інтерфейс, він не думає про зручність для користувача.

Так само аналітик-проєктувальник не бачить систему загалом і може залучатися до проєкту як експерт, який виявляє проблеми інтерфейсу, але сам їх не розв'язує. Отже, ідеальним варіантом роботи на проєкті $\epsilon$ спільна робота системного аналітика i аналітика-проєктувальника.

Аналітик великих даних (Аналітик Big Data). Цей спеціаліст аналізує, так звані, великі дані (Big Data), хоча насправді це можуть бути будь-які дані, і володіє знаннями, умінням, методами як обробляти, класифікувати, структурувати, зберігати, перетворювати дані та надавати їх в зручному 
вигляді всім зацікавленим посадовим особам. У бізнес-структурах таких аналітиків називають: математиками, математикамипрограмістами, інформаційними аналітиками, a іноді і системними аналітиками, але зі знаннями роботи 3 Big Data. Підгрунтям компетенцій таких фахівців $є$ математична освіта i знання в галузі математичної статистики, алгоритмів аналізу даних i математичного моделювання.

Аналітик-науковець 3 роботи 3 даними (Аналітик Data Scientist) Діяльність фахівця Data Scientist (Data Scientist - це наука про роботу з даними) спрямована на обробку інформації для формування висновків, пошуку прихованих закономірностей $\mathrm{i}$ добування знань 3 великих обсягів інформації. Подібні висновки особливо потрібні для підтримки прийняття стратегічних рішень, що досить актуально для вищого керівництва 3С України. Аналітик Data Scientist знаходиться на стику бізнес-аналізу (добре розбирається у процесах) i аналізу великих даних (часто можна побачити, що на позицію за цим напрямом використовуються фахівці зі знанням Big Data).

Фахівців 3 Data Scientist можна розподілити на аналітиків і програмістів, це вже новий напрям підготовки спеціалістів зі знанням аналізу та програмування. Такий спеціаліст повинен вміти програмувати свої математичні гіпотези i висновки для досягнення аналітичних цілей.

Результат роботи аналітика Data Scientist найчастіше не дуже помітний відразу, але його робота дуже корисна для розвитку структури організації і використовується для підтримки та прийняття стратегічних рішень керівниками, що зі свого боку вказує на необхідність таких фахівців в проєктах.

Інтеграційний аналітик. Під час ведення та реалізації великих проєктів зі значною кількістю різноманітних користувачів, а також у проєктах впровадження великого програмного продукту, коли його потрібно вбудувати в наявне IT-середовище, або навіть побудувати нове, для таких цілей необхідно виділяти окремий напрям інтеграції та аналітики.

Особливість роботи інтеграційного аналітика базується на з'єднанні систем в єдине ціле і в ідеальному випадку, отримуючи бізнес-процес від бізнес-аналітика, він може зрозуміти точки взаємодії інформаційних систем, що беруть участь у ньому, і спільно з аналітиком-архітектором опрацювати процес з'єднання. У самому простому розумінні інтеграція - це співставлення (mapping), тобто забезпечення інтероперабельності інформаційних потоків від однієї системи до іншої.

Отже, інтеграційний аналітик - це окремий випадок системного аналітика, який володіє знаннями роботи 3 технологіями i рішеннями побудови міжсистемної інтеграційної взаємодії.

Вірусний аналітик. У наш час 3 розвитком Інтернету підвищився ризик зараження інформаційних систем та окремих комп'ютерів різноманітними “вірусними" програмами.

Для проведення персонального захисту користувачі встановлюють антивіруси на персональні комп'ютери. Відповідно, і для загального захисту інформаційних систем потрібна посадова особа (особи), яка аналізує причини i наслідки роботи вірусу i, найголовніше, розробляє способи протидії вірусним атакам на систему. Такий аналітик постійно контролює розвиток інформаційної безпеки i допомагає захищати користувачів або інформаційні системи. Він ставить себе на місце розробника вірусу i намагається зрозуміти цілі та причини, його дії і методи захисту, які можливо застосувати в масштабі системи.

Вірусний аналітик, розуміючи роботу вірусу, пропонує варіанти захисту від нього, а також на підставі свого досвіду i знань, намагається випередити на крок розробників нових вірусів, а саме спрогнозувати поведінку нових вірусів i встигнути захистити користувачів та систему заздалегідь.

Висновок. Отже, успішне розроблення, впровадження та використання інформаційних систем у повсякденній діяльності структури (організації) 3С України можливе тільки за умови повноцінної та успішної діяльності робочої групи, до складу якої включено фахівців аналітичної складової.

3 огляду на викладене, щодо компетенції фахівців-аналітиків, які залучають під час розроблення, впровадження та супроводження інформаційних систем i запропонованої класифікації можна сказати, що загалом головне завдання IT-аналітика детальне вивчення структури організації, пошук проблем та оптимальних шляхів їх вирішення, він розробляє нову чи/або поліпшує стару бізнес-модель, оптимізує процес роботи та прагне збільшити спроможність організації. До того ж він повинен правильно відобразити погляди зацікавлених сторін та осіб у вигляді 
специфікації вимог i передати інформацію іншим особам, які беруть участь у проєкті.

$$
\text { IT-аналітики використовуються }
$$

великими підприємствами, банками, будівельними організаціями, IT-компаніями i, без сумніву потрібні ЗС України. На жаль, передовий досвід щодо кваліфікації та сертифікації фахівців-аналітиків в управлінні проєктами в державних установах, зокрема i 3С України майже не використовується, На сьогодні підготовка фахівців-аналітиків для використання в IT-серодовищі 3С України та створення відповідного підрозділу не ведеться, хоча така необхідність існує, такий підрозділ міг би бути “базисом" чи “інтеграційною шиною” для всіх систем.

Подальші дослідження за цією тематикою доцільно зосередити на питаннях розроблення механізму підготовки фахівціваналітиків для потреб ЗС України.

\section{СПИСОК ВИКОРИСТАНОЇ ЛІТЕРАТУРИ}

1. Петренко А. Щодо впровадження оборонного менеджменту та управління змінами в Міністерстві оборони України та Збройних Силах України : доп. Міністру оборони України від 04.06.2019 р.

2. Управління проектами : навчальний посібник до вивчення дисципліни / уклад.: Л. Є. Довгань, Г. А. Мохонько, І. П Малик. Київ : КПІ ім. Ігоря Сікорського, 2017. $420 \mathrm{c}$.

3. Оленіч А. В., Шацька 3. Я. Основні проблеми інформатизації Збройних Сил України на сучасному етапі. Актуальні проблеми економіки. 2012. № 10 (136). С. 136-142.

4. Ноздріна Л. В., Ящук В. І., Полотай О. І. Управління проєктами : підручник. Київ: Центр навчальної літератури, 2018. $432 \mathrm{c}$.

5. Oleksandr K. Як розвивати електронний уряд за відсутності державного фінансування. URL: http:// medium.com/@sashaeve/як-розвивати-електроннийуряд-за-відсутності-держфінансування-401abd88f09e

6. Леонтян М. А. Поняття “компетенція" "компетентність" у теорії освіти // Наукові праці Чорноморського державного університету імені Петра Могили комплексу "Києво-Могилянська академія". Педагогіка. 2012. Т. 188, Вип. 176, С. 73-75. URL: http://nbuv.gov.ua/UJRN/Npchduped_2012_188_176_18.

7 ДК 003:2010 Класифікатор професій. [Чинний від 2019-02-15]. URL: https:// mon.gov.ua/ storage/app/ media/ vyshcha/ IT-prof-standarty/5-ps-spes-infosystems13.12.2014.pdf.

8. A guide to the Business Analysis Body of Knowledge ${ }^{\circledR}$ (BABOK® Guide). URL: https://www.iiba.org/standardsand-resources/babok/.

9. RUP методология разработки. URL: https://qaevolution.ru/metodologiya-menedzhment/rup/.

10. Галаган В. I., Полішко С. В., Бондарчук С. В. Пропозиції щодо удосконалення процесу впровадження інформаційних систем іноземного виробництва в діяльність Збройних Сил України. Збірник наукових прачь Центру воєнно-стратегічних досліджень Національного університету оборони України імені Івана Черняховського. Київ, 2019. Вип. № 2 (66), С. 62-69.

11 Вигерс К., Битти Д. Разработка требований к программному обеспечению. 3-е изд., доп. Пер. с англ. Москва : Русская редакция; СПб. : БХВ-Петербург, 2014. 736 с. : ил. ISBN: 978-5-7502-0433-5 978-5-97753348-5.

Стаття надійшла до редакційної колегії 18.12.2019

\section{Justification of the professional competence of the participants in the working group on the development, implementation and maintenance of military information systems}

\section{Annotation}

The Ministry of Defense of Ukraine is at the stage of developing a conceptual model of defense management based on capabilities. Defense management incorporates principles and approaches adopted in NATO member states, as well as modern business practices adapted to programmatic and project management of the Armed Forces of Ukraine.

At present, training of analysts for use in the IT area of the Ukrainian Armed Forces and the creation of a corresponding unit is not underway, at the same time there is such a need, such a unit could be a "base" or "gate" for all systems.

Unfortunately, best practices in qualification and certification of analysts in project management in government agencies, including the Armed Forces of Ukraine, are hardly used.

The problem of attracting specialists with the necessary competencies during the development, implementation and maintenance is also the lack of a common understanding of their competence.

Successful development, implementation and use of information systems in the day-to-day operations of the Armed Forces of Ukraine is possible only on condition that the working group is full and successful, which includes specialists of analytical component.

Considering the classification of competencies of analysts who are involved in the development, implementation and maintenance of information systems, we can say that the main task of IT-analysts is to carefully study the structure of the organization, search for problems and optimal ways to solve them. In doing so, it must properly reflect the views of stakeholders and individuals in the form of a specification of requirements and pass on information to other parties involved in the project.

Keywords: IT-analysts, classification of IT-analysts, the requirements and skills of IT-analysts. 